by a patron who favours, protects, and gives influential support," it has a long and generally inglorious history in the development of careers in medicine. Medical students and junior doctors seek it. Their seniors bestow it with increasing effectiveness as their seniority increases. It is informal in operation, by its nature unequal in its distribution, and in practice a means of subverting both unredeemed meritocracy and the more complex goals of equality of opportunity.

Women lose out, ${ }^{2}$ as do ethnic minorities, which renders the effects of patronage both wasteful and unfair. Its principal practitioners and beneficiaries do not, of course, complain, but a BMA document just published expresses grave concerns about current realities and proposes far reaching reforms which, if implemented, would offer a fairer, better deal for all junior doctors ( $p$ 798). ${ }^{34}$

The document recognises that informal patronage could be seen as a response to widespread deficiencies in medical education, postgraduate training, appraisal, careers guidance, and appointments procedures. Individual and covert arrangements offer help and guidance to a favoured minority in overcoming a range of obstacles which nevertheless are faced by all. More open, more supportive, and more accountable mechanisms are now proposed. Were they to be realised, patronage might not disappear entirely but it would wither substantially as a result of being seen as increasingly unnecessary and underhand.

Financial and administrative constraints permitting, the proposed more open and formal systems of careers guidance, support, and appraisal could achieve much, especially if, as proposed, they were reinforced by explicit fairness in appointments procedures from preregistration level upwards and monitored for ethnic and gender neutrality under the auspices of the NHS Management Executive. And if self aware role modelling in medicine were to include a declared abstention from all the quiet words, phone calls, and fixings of the present highly selective mechanisms of patronage then the expectations of medical students and junior doctors, especially women and those from ethnic minorities, could be transformed, perhaps within only a generation or two.

COLIN CURRIE Honorary consultant in geriatric medicine

University Geriatric Medicine Unit,

City Hospital,

Edinburgh EH10 5SB

Ficklin FL, Browne VL, Powell RC, Carter JE. Faculty and house staff members as role models. f Med Educ 1988;63:392-6.

Joint Working Party. Women doctors and their careers. London: Department of Health, 1991

3 Working Party on the Career Progress of Doctors. Patronage in the medical profession. London: BMA, 1993.

4 Beecham L. Ad hoc patronage should end. BMF 1993;306:798.

\title{
Career grade posts in NHS trusts
}

\section{Patients will lose out if some trusts continue making unsafe appointments}

The procedures used by advisory appointment committees to appoint consultants have long been governed by successive statutory instruments of parliament ${ }^{1-3}$ for one reason only-to protect the public. The system has proved a remarkably cost effective way of ensuring that people are not appointed to consultant posts unless they have reached appropriate levels of training and experience. The royal colleges have a crucial role in ensuring the maintenance of standards through these procedures. Some other countries have created vastly expensive bureaucratic accrediting agencies to achieve the same ends.

Previously, regional health authorities were responsible for most consultant appointments, but since April 1991 more and more consultants are being employed directly by trusts. Unfortunately, there is increasing evidence that some trusts, particularly those in the "first wave," are trying to circumvent the current statutory instrument by such manoeuvres as appointing locums to non-existent posts or by using temporary consultant appointments.

Similarly, although trusts were reminded just one year ago of their obligation to abide by the manpower approvals procedures relating to non-consultant career grades, ${ }^{4}$ some have established posts clearly intended to be outside the controls incorporated in Achieving a Balance. This has ranged from posts being created without manpower approval to trusts inventing their own titles for grades, which results in grave confusion not only from a manpower perspective but also because different titles may imply competence not possessed by the post holder. Furthermore, because of their freedom to set their own terms of service, trusts are able to offer contracts that are potentially exploitative, requiring hours of work beyond those considered acceptable for doctors in the training grades.
Unfortunately, outposts of the NHS Management Executive, which are supposed to monitor trusts, have proved totally ineffectual in taking any action on this matter. But, sooner rather than later, trusts will have to realise that they can ignore neither the law of the land nor agreements to which ministers are cosignatories. The secretary of state has given the Joint Consultants Committee (JCC) an assurance that the Department of Health will deal firmly with specific cases of abuse that are notified to the department, and, indeed, certain trusts have already been made to reverse inappropriate appointments.

It is unlikely that the JCC knows of all the instances in which either advisory appointments committees' procedures have been bypassed or inappropriate non-consultant career grade appointments have been made. Doctors who are aware of such appointments in their hospitals (or plans for them) should notify the JCC's secretariat of the circumstances so that they may be taken up with the department without delay. The anonymity of doctors who provide these details will be guaranteed. If these practices are not stamped out it is the public who will be the ultimate victims.

\section{PADDY ROSS}

Chairman

Joint Consultants Committee,

BMA House,

London WC1H 9JP

\footnotetext{
Department of Health. Appointment of consultant regulations 1982. London: HMSO, 1982. (Statutory instrument 276.

instrument 276.)
Department of Health. NHS (appointment of consultants) amendment regulations 1990. London: HMSO, 1990. (Statutory instrument 1407.)

3 Department of Health. Appointment of consultant medical and dental staff to NHS trusts. (TEL(91)2.) Annex A. Direction under the NHS and Community Care Act 1990 on the appointment of consultants to NHS trusts. London: HMSO, 1991.

4 Beverley N. Letter to chief executives of NHS trusts. London: NHS Management Executive, 1992. (10 February.)
} 